\title{
EVOLUTIONAL NEUROLOGIC EVALUATION OF SEVEN YEAR-OLD CHILDREN BORN PREMATURELY
}

\author{
LYGIA OHLWEILER*, LGIA ALFANO**, NEWRA T. ROTTA***
}

\begin{abstract}
A sample of 51 children aged 7 with a history of prematurity was compared to 44 age-matched children who were born at term at the HCPA. The premature children had had gestational ages up to 37 weeks and 6 days and were bom weighing less than $2500 \mathrm{~g}$. The control group consisted of children born with gestational age between 38 and 42 weeks and weights above $2500 \mathrm{~g}$. The evaluation criteria were clinical examination, neurological examination and the evolutional neurological evaluation (ENE). The results pointed out that impulsiveness, aggressiveness, disorganization and enuresis were prevalent symptoms of developmental disturbances in the sample of prematures. Alterations at neurological examination did not discriminate between the two groups, although cerebral palsy occurred only in the proup of prematures. The ENE functions which differentiated the two groups studied were dynamic balance, appendicular and trunk-limb coordination and motor persistence.
\end{abstract}

KEY WORDS: prematurely born children, development, evolutional neurologic evaluation.

Avaliaçāo neurologica evolutiva aos sete anos de idade de crianças nascidas prematuras

RESUMO - Para estudar o desenvolvimento neuropsicomotor em amostra de prematuros aos 7 anos de idade, foram avaliadas 51 crianças prematuras e comparadas com 44 a termo. $O$ grupo de prematuros tinha idade gestacional de até 37 semanas e 6 dias e peso de nascimento ate $2500 \mathrm{~g}$. O grupo controle foi constituido de crianças com idade gestacional entre 38 e 42 semanas e acima de $2500 \mathrm{~g}$. Os instrumentos de avaliação utilizados foram os exames clinico, neurológico e neurológico evolutivo (ENE). Os resultados mostraram que impulsividade, agressividade, desorganização e enurese foram sintomas prevalentes nos prematuros. As alteraçðes no exame neurológico não discriminaram os grupos, embora paralisia cerebral só tenha ocorrido nos prematuros. As funçð̄es do ENE que distinguiram os grupos foram equilíbrio dinâmico, coordenação tronco-membros e persistência motora, constituindo-se esta no comprometimento dominante nos prematuros e as alterações na coordenação tronco-membros em achado peculiar neste grupo.

PALAVRAS-CHAVE: prematuridade, desenvolvimento neuropsicomotor, exame neurologico cvolutivo.

It has been well established that the development of the central nervous system (CNS) begins at conception and continues to adulthood. Psychomotor development has also been observed during intrauterine life ${ }^{22}$. CNS development is achieved through a series of transformations. An early phase of neuronal proliferation that occurs between the second and fourth month of gestation involves neurons and glial cells derived from the ventricular and sub-ventricular zones. During a second phase of neuronal migration, between the third and fifth month of gestation, millions of neurons move from their original site to their final locations. A third phase involves the organization that begins around the sixth month of gestation and persists for several years. Lastly, the final phase of neuronal maturation is related to the myelination that begins during the second trimester and continues throughout adult life ${ }^{9.29}$.

Department of Pediatrics, Hospital de Clinicas de Porto Alegre (HPCA), Universidade Federal do Rio Grande do Sul, School of Medicine, Brazil: *M.D., Assistant; **M.D., Pediatric Neurologist; ***M.D., Professor. Aceite: 15-março-1996.

Dra. Lygia Ohl weiler - Serviço de Neurologia , Hospital de Clinicas de Porto Alegre - Av. Ramiro Barcelos 2350 - 90035-007 Porto Alegre RS-Brasil. 
Reflex activity and muscle tone have been used to evaluate gestational age and differentiate between term and preterm newborns ${ }^{28}$. Fenichel considered premature those newborns borm at less than 38 weeks of gestational age and with a birth weight lower than $2500 \mathrm{~g}^{11}$. These considerations indicate that the criteria to evaluate neurologic maturity in newborns are not well established. The evaluation of children born preterm suggests that a number of disorders that may or may not be developmental in character can affect neurological performance in the areas of language, balance, motor coordination, lateral dominance and behavior. Medical literature on abnormalities in the neurological examination of premature children focuses mainly on visual and auditory deficits ${ }^{12,20,24}$. The prevalence of neurologic abnormalities seems to be inversely related to gestational age and is as high as $28 \%$ for major sequelae in groups of extremely premature children ${ }^{23}$. Neurologic problems seen in preterm children are not limited to the early years of life. Behavioral and learning disorders have been widely documented in such groups. However, transient abnormalities during the first year of life do not reliably predict school performance ${ }^{10}$.

Lefevre and colleagues used the evolutional neurologic evaluation (ENE) to evaluate language, lateralization, static and dynamic balance, appendicular coordination, trunk-limb coordination, syncinesis, muscle tone reflex and sensitivity, at ages 3 to 7 years old. They used a sample of 220 normal children in order to systematically define the normal performance patterns for each age group ${ }^{17}$.The ENE has been an useful tool in evaluating brain function and standardizing neurologic performance in children. It has been used to evaluate children with learning disabilities ${ }^{7.25}$, and to study the effect of imipramine on children with attention deficit hyperativity disorder ${ }^{14}$. A complete description of the ENE has been published elsewhere.

The present study tests the ENE as an instrument to evaluate children born prematurely. We conducted a cross sectional comparison of seven-year-old children that were born prematurely and matched controls, using ENE to determine the prevalence of neuropsychomotor developmental disorders.

\section{PATIENTS AND METHODS}

The sample was obtained from live births between July 1983 and June 1984 at the Hospital de Clinicas de Porto Alegre. Ninety-five children were selected and studied at age 7 years. Fifty-one children born prematurely according to the concept of neurologic prematurity proposed by Amiel-Tison and Fenichel and 44 children born at term were enrolled ${ }^{3.14}$. Patient selection was based on obstetric and medical records. Patients were contacted by mail in order to schedule the follow-up visits.

Children bom prematurely (gestational age equal or lower than 37 weeks and 6 days) were assigned to Group I. Group II was formed using children born immediately after the patients in Group I, who had gestational ages between 38 and 42 weeks and birth weight greater than $2500 \mathrm{~g}$.

Patients were submitted to a detailed physical examination, complete neurologic examination and ENE. The history was consistently obtained by one investigator. The physical examination and ENE were performed by another investigator who was not aware of each patient's perinatal history.

Data were compared using the chi-square test with Yates correlation and Fisher's exact test. $P<0.05$ was considered statistically significant.

\section{RESULTS}

Ninety-five children were enrolled in the study. Fifty-one children born preterm were assigned to Group I ( 25 females) and 44 children born at term were assigned to Group II ( 25 females). The birth weihgt and gestational age of children enrolled in the study are summarized in Table 1.

Data regarding behavior and school performance are shown in Table 2. Symptoms of impulsiveness $(\mathrm{P}=.001)$, aggressiveness $(\mathrm{P}=.025)$, disorganization $(\mathrm{P}=.015)$ and nocturnal enuresis $(\mathrm{P}=.001)$ were significantly more prevalent among children from Group I. Enuresis and impulsiveness were found only among children from Group $I$.

The neurologic exam was abnormal in 11 children from Group $1: 4(7.8 \%)$ had clinical findings compatible with cerebral palsy, $6(11.7 \%)$ were hypotonic, and $1(1.9 \%)$ had sensory-neural hearing loss. Among children from Group II, $4(9 \%)$ had some degree of hypotonia. These differences between both groups were not statistically significant. 
Table 1. Newnborn (NB).

\begin{tabular}{lccc}
\hline Weight & NB & Gestational age & NB \\
\hline$<1000 \mathrm{~g}$ & 1 & & \\
$1000-1499 \mathrm{~g}$ & 3 & $28-31$ weeks & 6 \\
$1500-1999 \mathrm{~g}$ & 14 & $32-37$ weeks & 45 \\
$2000-2500 \mathrm{~g}$ & 33 & $38-44$ weeks & 44 \\
$>2500 \mathrm{~g}$ & 44 & & \\
\hline
\end{tabular}

Table 2. Behavior and school performance.

\begin{tabular}{lccc}
\hline & Group I & Group II & p value \\
\hline Impulsiveness & 13 & 0 & $0.001^{*}$ \\
Aggressiveness & 12 & 2 & $0.025^{*}$ \\
Disorganization & 18 & 6 & $0.015^{*}$ \\
Enuresis & 11 & 0 & $0.001^{*}$ \\
Learning disability & 10 & 8 & 0.859 \\
Hyperactivity & 15 & 6 & 0.064 \\
Motor debility & 14 & 5 & 0.05 \\
\hline
\end{tabular}

* Statistic significance

Table 3. volutional neurological exam.

\begin{tabular}{lcccccc}
\hline & \multicolumn{3}{c}{ Group I } & & \multicolumn{2}{c}{ Group II } \\
\cline { 2 - 3 } \cline { 5 - 6 } & $\mathrm{N}$ & $\mathrm{A}$ & & $\mathrm{N}$ & $\mathrm{A}$ & p value \\
\hline Stance & 31 & 18 & & 27 & 17 & 0.85 \\
Dynamic balance & 29 & 20 & & 35 & 9 & $0.034^{*}$ \\
Appendicular coordination & 12 & 37 & & 23 & 21 & $0.005^{*}$ \\
Trunk-limbs coordination & 38 & 9 & & 42 & 2 & $0.032^{*}$ \\
Motor persistence & 27 & 22 & & 38 & 6 & $0.001^{*}$ \\
Sensation and gnosias & 25 & 24 & 25 & 19 & 0.575 \\
\hline
\end{tabular}

* Statistically significant diferences

Three children (5.8\%) in Group I had dyslalias: one child was found to have dyslalia with phonetic exchange and suppression while two children had only phonetic exchange. There was no statistical difference between both groups.

Table 3 summarizes the ENE findings. There was a significant difference between both groups with respect to dynamic balance $(\mathrm{P}=.034)$, appendicular coordination $(\mathrm{P}=.005)$, trunk-limb coordination ( $\mathrm{P}=.032)$ and motor persistence $(\mathrm{P}=.001$ ) (Figs 1 to 6 ).

\section{DISCUSSION}

It is well-known that gender influences birth weight and that a comparable population of male babies has a slightly greater birth weight than females babies. There is also a lower prevalence of live births with weight below $2500 \mathrm{~g}$ among boys ${ }^{5}$. In our study there was an equivalent number of male and female children in each group, allowing us to disregard potential differences due to overrepresentation of one of the genders.

The World Health Organization's 9th Review of the International Classification of Causes of Death and Diseases suggests that newborns should be classified according to birth weight in groups with less than $1000 \mathrm{~g}, 1000-1499 \mathrm{~g}, 1500-1999 \mathrm{~g}$ and $2000-2499 \mathrm{~g}$. In our study most children had a moderately low birth weight, between $1500 \mathrm{~g}$ and $2000 \mathrm{~g}$ (Table 1). These children represented a group of low risk preterm newborns ${ }^{45}$.

Among the 95 children studied, 14 were born at 37 weeks of gestational age. When their neurologic performance was evaluated using ENE, 12(85.7\%) children did not perform as expected 


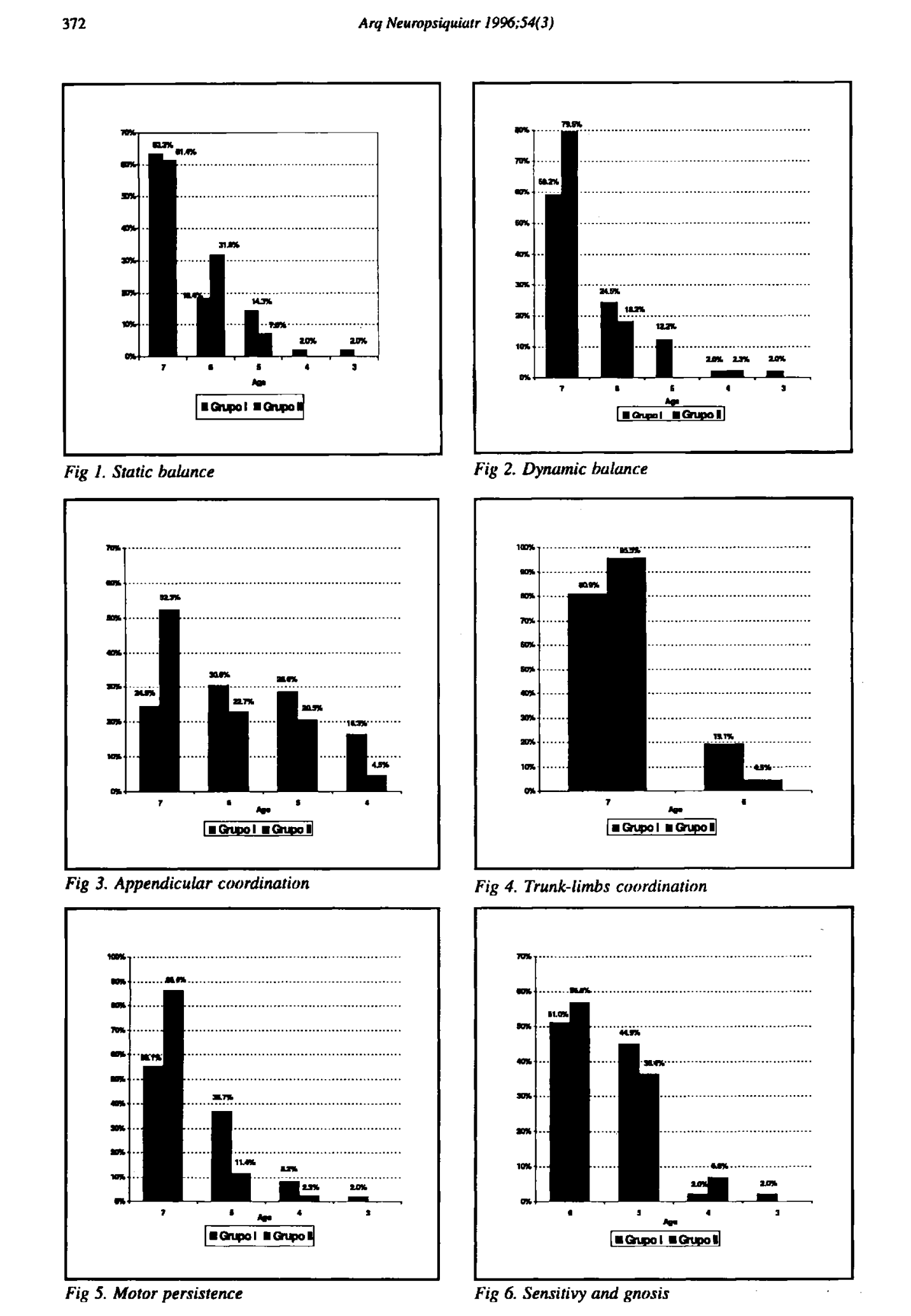


for their age group. This result agrees with data by Saint-Anne Dargassies ${ }^{27,28}$ and Fenichel ${ }^{11}$ in classifying children bom at 37 weeks gestational age as prematures.

Fedrizzi, Zuccarino and Vizziello studied low risk preterm newborns and term newborns for 7 years and did not observe major sequelae such as cerebral palsy or mental retardation, concluding that neurologic abnormalities during the first year of life have no predictive value for future school problems ${ }^{10}$. Children that were born prematurely and small for gestational age (SGA) were more likely to be hyperactive when compared to children born prematurely and adequate for gestational age (AGE) and term ${ }^{25}$.

In our study, we found that both groups differed significantly regarding pre-school and school history as to impulsiveness, aggressiveness and disorganization (Table 2) and these data are compatible with those of others.

We found nocturnal enuresis to be present only among children born prematurely (Group I). Saint-Anne Dargassies found that a high percentage of preterm children had transient enuresis as a symptom of neurologic immaturity ${ }^{27}$.

Language development has been found to be delayed in children born prematurely ${ }^{12,21}$. Our results did not show a significant difference between both groups. However, 3 children in Group I had dyslalias, 1 had dysartria and 1 was a deaf-mute, while in Group II only 1 child had dyslalia with phonetic exchange, indicating a trend towards greater impairment in the premature group.

We found 4 children with a neurologic exam compatible with cerebral palsy and 1 with neurosensory hearing loss, all in the preterm group. These findings are concurrent with others who found a high incidence of abnormalities in the neurologic exam of children born preterm, specially visual and hearing problems

In our study $63.3 \%$ of children from Group I and $61.4 \%$ from Group II performed as expected in tests for the 7-year-old age group. Static balance was a part of the ENE that did not discriminate between children born prematurely and the control group (Table 3 ). Our results differ from those of Forslund who tested 41 children born at less than 35 weeks of gestational age against a group of 24 children born at term and found that the preterm group had decreased postural control ${ }^{13}$.

Fifty-nine percent of the children in Group I and $79.5 \%$ in Group II were able to perform the dynamic balance tests for the 7-year-old age group (Fig 2). This statistically significant result is similar to that of other series ${ }^{7,26}$ and underscores the importance of the dynamic balance tests in the evaluation of children with psychomotor development disorders.

The appendicular coordination was able to discriminate between both groups of children as $24.6 \%$ of children in Group I and $52.3 \%$ of children in Group II were able to perform the tests for the 7 -year-old age group (Figure 3). Similar results were found by others who observed problems with fine motor skills and coordination in groups of children of low gestational age $e^{8.13 .15}$.

We found that trunk-limb coordination was statistically significant when comparing both groups of children (Table 3). This finding was not observed by authors who studied children with learning disabilities ${ }^{26}$, children born to hypertensive mothers ${ }^{2}$ and children with attention deficit disorder with hyperactivity ${ }^{14}$ and seems to be somewhat specific to the group of preterm children.

Fifty-five percent of children in Group I and $86.4 \%$ in Group II were able to perform the tests for motor persistence for the 7-year-old age group (Fig 5). Our results agree with those expected in the literature on small for gestational age, for children born to hypertensive mothers and children with attention deficit with hyperactivity $27,14,16,18$.

Lezine followed 127 children born preterm up to 12 years of age and observed difficulties in body image knowledge and representation ${ }^{19}$. In our study the tests for sensitivity and gnosis did not differ between both groups (Table 3). 


\section{CONCLUSIONS}

We conclude that impulsiveness, aggressiveness and enuresis were prevalent symptoms of developmental disorders in the group of children born preterm at a seven year follow up. The routine neurologic examination could not able to discriminate between the group of children born preterm and those born at term. However, tests that are part of the ENE such as dynamic balance, appendicular coordination, trunk-limb coordination and motor persistence were able to discriminate between both groups at the age of 7 years.Disorders of the trunk-limb coordination associated with prematurity in our sample constitute unique finding.

\section{REFERENCES}

1. Alberman E, Evans SJW. A epidemiologia da prematuridade: etiologia, frequencia e prognóstico. Anais Nestlé 1992;44:5-24.

2. Alvarez-Silva CR. Avaliação neurológica evolutiva de filhos de gestantes com hipertensāo arterial crônica. Tese de Mestrado, Faculdade de Medicina Ribeirāo Preto da Universidade de São Paulo. Ribeirão Preto, 1985.

3. Amiel-Tison C. Neurological avaluation of the maturity of newborn infants. Arch Dis Child 1968;43:89-93.

4. Battaglia F, Lubchenco L. A practical classificution of newborn infants by weight and gestationul age. J Pediatr 1967;71:159.

5. Behrman R, Hirsch RP, Fria TJ, Shapiro SM, Holzman I, Painter MJ. Cause of hearing loss in the high risk premature infant. J Pediatr 1985; 106:95-101.

6. Bergman I, Shiono P. Neonatal risk factors. In Fanaroff AA, Martin RJ. Neonatal-perinatal medicine (Diseases of the fetus and infant). Ed 5. St Louis: Mosby, 1992.

7. Cypel S. Avaliação neurológica e de alguns aspectos do comportamento em crianças de 6 a 7 anos com e sem dificuldades do aprendizado. Tese de Livre Docência, Faculdade de Medicina da Universidade de Sāo Paulo. São Paulo, 1983.

8. Felliman AM, Bryan EM, Elliman AD, Walker J, Harvey DR. Coordination of low birthweight seven-years-olds. Acta Paediatr Scand 1991;80:316-322.

9. Escobedo MB. Follow-up of prematurely born infants. Clin Obstetr Gynecol 1988;31:662-667.

10. Fedrizzi E, Zuccarino ML, Vizziello P. Clinical problems in neurodevelopmental diugnosis: a 7-year neurological and psychological follow-up study of low risk preterm infants. Ital J Neurol Sci 1986;5:117-126.

11. Fenichel GM. Neonatal neurology (The neurologicul consultation). New York: Churchill Livinstone 1990:1-16.

12. Forslund M. Growth and motor performance in preterm children at 8 years of age. Acta Paediatr 1992;81:840-842.

13. Forslund M, Bjerre I. Follow-up of preterm children: II. Growth and development at four years of uge. Early Hum Dev 1992;24:107-110.

14. Guardiola A. Uso da imipramina no distúrbio de hiperatividade com déficit de atenção. Tese de Mestrado, Fundaçăo Faculdade Federal de Ciências Médicas de Porto Alegre, Porto Alegre, 1990.

15. Holmqvist P, Pleven H, Svenningsen NW. Vaginally born low-risk infants: fetal acidosis and outcome at 6 years of age. Acta Paediaur Scand 1988;77:638-641.

16. Klein NR, Hack M, Breslau N. Children who were very low birthweight: development and academic achievement at nine years of age. J Dev Behav Pediatr 1989;10:32-37.

17. Lefevre AB. Exame neurológico evolutivo. São Paulo: Sarvier, 1972.

18. Lefevre AB. Disfunçāo cerebral mínima: estudo multidisciplinar. São Paulo: Sarvier; 1975.

19. Lezine I. El desarollo psicomotor del nino. México: Grijalbo, 1971.

20. Lubchenco LO, Hansman C. Dressler M, Boyd E. Intrauterine growth us estimated from liveborn birth-weight dath at 24 to 42 weeks of gestation. Pediatrics 1963;32:793-800.

21. Michelsson K, Noronen M. Neurological psychological and articulatory impairment in five-year-old children with a birthweight of 2000g or less. Eur J Pediatr 1983;141:96-100.

22. Minkowskj M. Neuropsicologia y pediatria (Acerca de la evolucion anátomo-fisiológica de las funciones cerebrales en el lactente parvulo). Buenos Aires: Alfu, 1956.

23. Nickel RE, Brennett FC, Lamson FN. School performance of children with birthweights of $1000 \mathrm{~g}$ or less. Am J Dis Child 1982;136:105-110.

24. Ounted MK, Moar VA, Scott A. Small for dates babies at the age of four years: health, handicap and developmental status. Early Hum Dev 1983;8:243-258.

25. Robertson CM, Etches PC, Kyle JM. Eight-year school performance and growth of preterm, small for gestational age infants: a comparative study with subjects matched for birth weight or for gestational age. J Pediatr 1990;116:19-26.

26. Rotta NT. Avaliução neurológica evolutiva, eletrencefalográfica e psicológica em crianças com rendimento escolar deficiente. Tese de Livre Docência. Faculdade de Medicina da Universidade de São Paulo. São Paulo, 1975.

27. Saint-Anne Dargassies, S. Normality and normalization as seen in a long-term neurological follow-up of 286 truly premature infants. Neuroplddiatrie 1979;10:226-242.

28. Saint-Anne Dargassies, S. As bases da neurologia do desenvolvimento do luctente. São Puulo: Manole:1980:25-40.

29. Volpe JJ. Neurology of the newborn. Ed 3. Philadelphia: Suunders, 1995:43-92. 